\title{
Oral rehydration solution containing trisodium citrate for treating severe diarrhoea: controlled clinical trial //
}

\author{
Ramendra N Mazumder, S K $\mid$ Nath, H $[$ Ashraf, \\ F C Patra, A N]Alam
}

International Centre for Diarrhoeal Disease Research, Bangladesh ) PO Box 128(Dhaka)1000, Bangladesh

- Ramendra N Mazumder, $\mathrm{MB}$, medical officer $S$ K Nath, MB, senior medical officer $\mathrm{H}$ Ashraf, $\mathrm{MB}$, medical officer F C Patra, MB, research fellow A N Alam, MB, head of clinical research centre

Correspondence to: Dr Mazumder.

$B M \mathcal{Y}$ 1991;302:88-9
Oral rehydration solutions are highly effective for treating most patients with dehydration due to diarrhoea. Early formulations contained glucose and three salts: sodium chloride, sodium bicarbonate, and potassium chloride. Subsequently, a formulation containing trisodium citrate dihydrate instead of sodium bicarbonate was shown to be more stable under high humidity and temperature conditions and equally effective in treating dehydration and acidosis due to diarrhoea'; in one study of patients with cholera the severity of purging was significantly less and in another study there was a similar trend. ${ }^{23}$ In a randomised double blind trial we compared the two solutions.

\section{Patients, methods, and results}

We studied males aged 8-56 years with diarrhoea of less than 48 hours' duration and signs of severe dehydration who had not received any antibiotics. Fluid was replaced by intravenous acetate solutions over about four hours. A stool specimen was obtained to isolate diarrhoeal pathogens. After hydration patients were randomly assigned to receive either a citrate oral rehydration solution $(n=90)$ or a bicarbonate solution $(n=90)$. Packets were provided by the World Health Organisation in a randomised sequence bearing patient serial numbers; the randomisation code was kept with the organisation. The citrate solution (osmolality $311 \mathrm{mmol}$ ) contained trisodium citrate $10 \mathrm{mmol} / \mathrm{l}$ and the bicarbonate solution (331 mmol) contained sodium hydrogen carbonate $30 \mathrm{mmol} / \mathrm{l}$. Both solutions looked identical and were provided at the bedsides of patients, who drank freely until diarrhoea stopped; food was withheld for 24 hours.

The volume of stools, vomit, and urine and the amount of solution consumed were recorded every eight hours until the diarrhoea had stopped (that is, passage of the last liquid stool). Patients received tetracycline $(50 \mathrm{mg} / \mathrm{kg}$ in $24 \mathrm{~h}$ with a maximum of $2 \mathrm{~g} /$ day) orally for 48 hours starting 24 hours after starting oral rehydration. Patients who became dehydrated during oral replacement were given rapid intravenous infusion followed by oral treatment. Data were analysed by the SPSS PC+ package and significance of outcome variables examined by the rank sum test.

Patients' age, sex, and severity of diarrhoea were similar in both groups. Vibrio cholerae and enterotoxigenic Escherichia coli were the two main pathogens isolated $(88 \%$ of patients receiving citrate solution and $87 \%$ of those receiving bicarbonate solution). Seven patients (four receiving citrate and three bicarbonate) were excluded from the analysis because of absence of diarrhoea after starting treatment or incomplete stay, or both.

As the first 24 hours are most critical in cholera and diarrhoea due to $E$ coli we did evaluations within this period. The table shows that during the first $24 \mathrm{~h}$ of oral rehydration the stool volume was significantly $(p=0.05)$ less (by $11 \%$ ) in those receiving citrate than in those receiving bicarbonate.

\section{Discussion}

Stool reduction with citrate solution may be related to enhanced absorption by enterocytes. ${ }^{4}$ The lower luminal osmolality of the citrate solution $(311 \mathrm{mmol})$ than the bicarbonate solution $(331 \mathrm{mmol})$ may have contributed. The total stool volume up to recovery was not, however, significantly different between groups. The intake of solution was significantly $(p=0.01)$ less (by $18 \%$ ) in those receiving citrate solution than in those receiving bicarbonate solution; this finding is compatible with the reduced purging in those receiving citrate solution.

Our patients had mild acidosis (table) before starting treatment; after $24 \mathrm{~h}$ carbon dioxide concentrations were normal, showing the ability of trisodium citrate in oral solution to provide base and correct acidosis. Serum concentrations of other electrolytes were similar and normal after $24 \mathrm{~h}$. Forty six patients ( $26 \%$ ) became dehydrated and required short courses of intravenous infusion during oral replacement. Previous studies show that despite antibiotic treatment from the beginning, $16 \%$ of patients with cholera treated with oral solutions alone may need short courses of intravenous infusions. ${ }^{5}$ No significant difference between the two groups was observed in duration of diarrhoea.

We conclude that citrate oral rehydration solution is not only highly stable with a long shelf life but also reduces fluid loss and oral fluid requirements in patients with acute diarrhoea. It is as effective as bicarbonate solution in preventing acid-base abnormalities.

This research was supported by a grant from the Programme for Control of Diarrhoeal Diseases, World Health Organisation, Geneva. We thank Dr Dilip Mahalanabis for

Course of illness, stool and urine outputs, and intake of solutions in males with diarrhoea treated for severe dehydration with oral citrate or bicarbonate rehydration solution. Figures are median (quartile) values unless stated otherwise

\begin{tabular}{|c|c|c|c|c|}
\hline & $\begin{array}{c}\text { Those treated } \\
\text { with bicarbonate } \\
\text { solution } \\
(\mathbf{n}=87)\end{array}$ & $\begin{array}{l}\text { Those treated } \\
\text { with citrate } \\
\text { solution } \\
(n=86)\end{array}$ & p Value ${ }^{\star}$ & $\begin{array}{l}95 \% \text { Confidence } \\
\text { interval for } \\
\text { difference } \\
\text { between medians }\end{array}$ \\
\hline $\begin{array}{l}\text { No who vomited during oral treatment } \\
\text { Stool output }(\mathrm{ml} / \mathrm{kg}) \text { : }\end{array}$ & 37 & 39 & $0 \cdot 82 \dagger$ & \\
\hline $\begin{array}{l}\text { During first } 24 \mathrm{~h} \\
\text { Total }\end{array}$ & $\begin{array}{l}306(191,434) \\
390(247,539)\end{array}$ & $\begin{array}{l}272(99,389) \\
366(112,516)\end{array}$ & $\begin{array}{l}0 \cdot 05 \\
0 \cdot 10\end{array}$ & $\begin{array}{l}-1.54 \text { to } 105 \\
-18 \text { to } 118\end{array}$ \\
\hline \multicolumn{5}{|l|}{ Intake of oral rehydration solution $(\mathrm{ml} / \mathrm{kg})$ : } \\
\hline During first $24 \mathrm{~h}$ & $405(294,514)$ & $330(221,446)$ & 0.01 & 10 to 118 \\
\hline Total & $494(359,683)$ & $410(232,659)$ & $0 \cdot 13$ & -18 to 147 \\
\hline Total intake of water $(\mathrm{ml} / \mathrm{kg})$ & $41(17,80)$ & $43(15,73)$ & 0.88 & -10 to 12 \\
\hline Total urine output $(\mathrm{ml} / \mathrm{kg})$ & $162(99,262)$ & $169(108,243)$ & $0 \cdot 92$ & -34 to 28 \\
\hline Duration of diarrhoea & $48(39,56)$ & $48(32,56)$ & $0 \cdot 32$ & -0.45 to 8 \\
\hline Total intake of oral plus intravenous solutions $(\mathrm{ml} / \mathrm{kg})$ & $549(400,769)$ & $543(315,712)$ & 0.25 & -36 to 137 \\
\hline \multicolumn{5}{|l|}{ Mean (SD) plasma carbon dioxide $(\mathrm{mmol} / \mathrm{l})$ : } \\
\hline On admission & $13 \cdot 4(3 \cdot 5) \ddagger$ & $13 \cdot 6(3 \cdot 7)$ & & \\
\hline At $28 \mathrm{~h}$ & $22 \cdot 8(4 \cdot 3) \bigcap$ & $21 \cdot 7(4 \cdot 7)$ & & \\
\hline $\begin{array}{l}\text { No who received unscheduled intravenous } \\
\text { rehydration solution during studyt }\end{array}$ & 22 & 24 & $0.82 \dagger$ & \\
\hline
\end{tabular}

$\star$ By Wilcoxon rank sum test for independent samples.

$\dagger$ †y $\chi^{2}$ test.

$\ddagger N=86$.

$\$ \mathrm{~N}=75$ 
his guidance and help with statistical analysis and in preparing this manuscript.

1 Siewert M, Gnekow H. Uber die Stabilitat von Glucose-Elektrolyt-Mischunge (oral rehydration salts: ORS) zur Therapeutie von Durchfallerankungen). Pharmazeutische Zeitung 1983;128:1169-74.

2 Hoffman SL, Moechtar MA, Simajutank C, et al. Rehydration and maintenance therapy of cholera patients in Jakarta: citrate-based versus bicarbonate-based oral rehydration salt solution. F Infect Dis 1985;152:1159-65.
3 Islam MR, Samadi AR, Ahmed SM, Bardhan PK, Ali A. Oral rehydration therapy: efficacy of sodium citrate equals to sodium bicarbonate for correction of acidosis in diarrhoea. Gut 1984;25:900-4.

4 Newsome PM, Burgess MN, Homlman GD. Stimulation of ileal absorption by sodium citrate. Scand F Gastroenterol 1983;18(suppl 87):119-21.

5 Patra FC, Sack DA, Islam A, Alam AN, Mazumder RN. Oral rehydration formula containing alanine and glucose for treatment of diarrhoea: controlled trial. $B M \mathcal{1}$ 1989;298:1353-6.

(Accepted 2 November 1990)
Otago Medical School, $\mathbf{P O}$ Box 913, Dunedin, New Zealand) Ian M St George, FRNZCGP, senior lecturer, general practice department

Sheila Williams, BSC, biostatistician, preventive and social medicine departmen Warren R Stanton, PHD, research fellow, Dunedin multidisciplinary health and development research unit Phil A Silva, PHD, director, Dunedin multidisciplinary health and development research unit

Correspondence to: $\mathrm{Dr} \mathrm{St}$ George.

BMF 1991;302:89-90
Among the immediate effects of inhaling cigarette smoke is a rise in heart rate and blood pressure as a result of the action of nicotine at a number of sites effecting neurocardiovascular control. Many studiesfor example, that by Simpson et al' - have found lower average systolic and diastolic blood pressures in adults who smoked than in non-smokers.

\section{Methods and results}

The sample and techniques of measurement used in this study have been detailed elsewhere. ${ }^{2}$ Children born between 1 April 1972 and 31 March 1973 in Dunedin were seen at intervals of two years. Sample selection, attrition, and changes in characteristics with time have been described by Silva. ${ }^{3}$

Measures of smoking, cardiovascular fitness, exercise tolerance, and body size were available for 839 children at age 15 .

Blood pressures were obtained at rest and during a standard six minute submaximal cycle ergometer test: before exercise, while seated on the cycle at rest immediately after the sixth minute of exercise; and after five minutes' recovery.

Smoking histories were obtained at ages 11 and $15 .^{4}$ Blood pressures at age 15 were compared for five groups, defined in terms of their smoking history at age 15: those who had never smoked, had smoked infrequently but not in the past two years, had smoked infrequently in the past two years, had smoked occasionally in the past four weeks, and smoked daily Analyses of variance and covariance were used.

The table shows means for various systolic blood pressure measures. There was a significant difference among the smoking groups for both unadjusted and adjusted systolic blood pressure at rest and before exercise. After adjustment for height, weight, and sex the difference in blood pressure between the nonsmoking group and the group who smoked daily was $4.3(95 \%$ confidence interval 1.8 to $6 \cdot 8) \mathrm{mm} \mathrm{Hg}$ for resting systolic blood pressure and $4 \cdot 8(2 \cdot 1$ to $7 \cdot 5) \mathrm{mm} \mathrm{Hg}$ for systolic blood pressure before exercise.

The differences among systolic blood pressures during exercise were not significant, but there were differences for blood pressure after recovery: these were smaller but remained significant after adjustment, suggesting differences in recovery rate among the groups.

The differences in diastolic blood pressure among the groups were not significant. The differences for the blood pressures at age 11 among the 15 year olds who smoked were not significant.

\section{Comment}

Explanations suggested for lower interval blood pressure in adult smokers have included lower weight, differences in alcohol consumption, relief of stress by smoking, or a lower "sympathetic tone." Some researchers have even suggested that smokers with hypertension die younger than non-smokers, leaving a population of smokers with lower than average blood pressures.

Our results were similar in direction and magnitude to those found in adult smokers and suggest an effect at least on systolic blood pressure, evident even in young occasional smokers. This effect was not apparent during exercise, suggesting it can be overcome by increased catecholamine release. That the differences had not been evident four years earlier suggests that they were caused by smoking.

Selective mortality does not apply at age 15 and the effect of body size has been adjusted for in the present study. A reduction in sympathetic activity evident in the intervals between smoking seems the only tenable explanation.

The Dunedin Multidisciplinary Health and Development Research Unit has been funded principally by the Medical Research Council of New Zealand. The cardiovascular aspects of the research have been generously supported over eight years by grants from the National Heart Foundation of New Zealand.

Means and adjusted means for systolic blood pressure ( $\mathrm{mm} \mathrm{Hg}$ ) measured at age 15 in terms of smoking history at age 15

\begin{tabular}{|c|c|c|c|c|c|c|c|}
\hline \multirow[b]{2}{*}{ Systolic blood pressure } & \multirow[b]{2}{*}{$\begin{array}{l}\text { Never smokers } \\
\quad(n=167)\end{array}$} & \multicolumn{4}{|c|}{ Smokers } & \multirow[b]{2}{*}{$\begin{array}{l}\text { Error root mean } \\
\text { square }\end{array}$} & \multirow[b]{2}{*}{$\mathrm{p}$ Value } \\
\hline & & $\begin{array}{l}\text { Not in past } 2 \text { years } \\
\qquad(\mathrm{n}=210)\end{array}$ & $\begin{array}{l}\text { Infrequently in past } 2 \\
\text { years }(n=241)\end{array}$ & $\begin{array}{l}\text { Occasionally in past } 4 \\
\text { weeks }(n=110)\end{array}$ & $\underset{(n=103)}{\text { Daily }}$ & & \\
\hline Resting & $127 \cdot 1$ & $125 \cdot 7$ & $124 \cdot 2$ & $124 \cdot 2$ & $122 \cdot 3$ & $10 \cdot 87$ & 0.004 \\
\hline $\begin{array}{l}\text { Adjusted for sex, } \\
\text { height, and weight }\end{array}$ & 124.9 & $123 \cdot 6$ & $122 \cdot 6$ & $123 \cdot 3$ & $120 \cdot 6$ & $10 \cdot 05$ & 0.024 \\
\hline Before exercise & $114 \cdot 7$ & 112.5 & 111.0 & 111.0 & $109 \cdot 3$ & 11.71 & $\begin{array}{l}0.024 \\
0.002\end{array}$ \\
\hline $\begin{array}{l}\text { Adjusted for sex, } \\
\text { height, and weight }\end{array}$ & $114 \cdot 2$ & $112 \cdot 3$ & $111 \cdot 2$ & $111 \cdot 8$ & $109 \cdot 4$ & $10 \cdot 87$ & 0.008 \\
\hline $\begin{array}{l}\text { During exercise } \\
\text { Adjusted for systolic } \\
\text { blood pressure before } \\
\text { exercise, sex, height, }\end{array}$ & $158 \cdot 9$ & $157 \cdot 6$ & $156 \cdot 7$ & $156 \cdot 1$ & $155 \cdot 0$ & $14 \cdot 93$ & $0 \cdot 261$ \\
\hline $\begin{array}{l}\text { and weight } \\
\text { Recovery }\end{array}$ & $\begin{array}{l}157 \cdot 4 \\
112 \cdot 2\end{array}$ & $\begin{array}{l}157 \cdot 0 \\
109 \cdot 7\end{array}$ & $\begin{array}{l}157 \cdot 1 \\
108 \cdot 7\end{array}$ & $\begin{array}{l}156 \cdot 8 \\
106 \cdot 5\end{array}$ & $\begin{array}{l}156 \cdot 6 \\
108 \cdot 0\end{array}$ & $\begin{array}{l}13 \cdot 78 \\
10 \cdot 29\end{array}$ & $\begin{array}{l}0.990 \\
0.000\end{array}$ \\
\hline $\begin{array}{l}\text { Adjusted for pre- } \\
\text { exercise systolic, sex, } \\
\text { height and weight }\end{array}$ & $110 \cdot 6$ & $109 \cdot 3$ & $109 \cdot 1$ & $107 \cdot 2$ & $109 \cdot 4$ & $7 \cdot 64$ & 0.014 \\
\hline
\end{tabular}

